Article

\title{
Oxidation Resistance and Wetting Behavior of MgO-C Refractories: Effect of Carbon Content
}

\author{
Zhaoyang Liu ${ }^{\mathbb{D}}$, Jingkun Yu *, Xin Yang, Endong Jin and Lei Yuan \\ School of Metallurgy, Northeastern University, Shenyang 110819, China; \\ zhaoyangliu@stumail.neu.edu.cn (Z.L.); 18241279158@163.com (X.Y.); \\ 1510238@stu.neu.edu.cn (E.J.); yuanl@smm.neu.edu.cn (L.Y.) \\ * Correspondence: yujk@smm.neu.edu.cn; Tel.: +86-024-83681576; Fax: +86-024-83689981
}

Received: 10 May 2018; Accepted: 23 May 2018; Published: 24 May 2018

check for updates

\begin{abstract}
Various carbon contents in the $\mathrm{MgO}-\mathrm{C}$ refractory were studied with respect to the oxidation resistance and the wetting behavior with slag. The bulk density, apparent porosity, cold crushing strength, oxidation rate, and mass loss rate of the fired $\mathrm{MgO}-\mathrm{C}$ refractories with various carbon contents were measured and compared. The wetting and penetration behavior of the cured $\mathrm{MgO}-\mathrm{C}$ refractory with the molten slag were observed in-situ. The contact angle and the shape parameters of molten slag, including the apparent radius, height, and volume were compared. The results showed that the regenerated $\mathrm{MgO}$ effectively restrained the carbon oxidation in the $\mathrm{MgO}-\mathrm{C}$ refractory, which was more evident at the low carbon content refractory. The contact angle between the $\mathrm{MgO}-\mathrm{C}$ refractory and the molten slag increased as the carbon content increased. The increased contact angle decreased the penetration of the molten slag.
\end{abstract}

Keywords: oxidation resistance; wetting behavior; $\mathrm{MgO}-\mathrm{C}$ refractories; carbon content

\section{Introduction}

Carbon bonded magnesia (MgO-C) refractory is commonly used in the iron- and steelmaking process, especially in the lining of electric furnaces, converters, and ladles [1]. The $\mathrm{MgO}-\mathrm{C}$ refractory is subjected to extreme circumstances, including ultra-high temperature, severe convection, and oxidizing atmospheres, where it becomes damaged and its service life is shortened [2,3]. Many studies have investigated the mechanism of the degradation of $\mathrm{MgO}-\mathrm{C}$ refractory in slag or slag-steel systems via stationary or rotary immersion methods [4-6]. Jansson et al. [7] suggested that dissolution of the $\mathrm{MgO}$ into the slag was the first step in the corrosion of the $\mathrm{MgO}-\mathrm{C}$ refractory, followed by penetration of the grain boundaries and dispersion of the grains in the slag. At the same time, the experiments results [8] showed that the mass loss of $\mathrm{MgO}-\mathrm{C}$ refractory was directly dependent on the oxygen potential in the ambient atmosphere. The mechanism of MgO-C refractory degradation primarily consists of the carbon oxidation and the $\mathrm{MgO}$ dissolution.

Carbon plays an important role in improving the thermal shock resistance and the slag corrosion resistance of the $\mathrm{MgO}-\mathrm{C}$ refractory, due to its low thermal expansion coefficient and its poor wettability with slag [9]. However, carbon is susceptible to oxidation [10], particularly in high temperatures, which is classified into direct (Equation (1)) and indirect oxidation (Equation (2)). Numerous studies have shown that many factors, such as porosity [11], reactivity of the graphite [12], gas composition, and flow characteristics [13], could dramatically affect the direct oxidation rate of the refractory. Also, the oxidation kinetics of the $\mathrm{MgO}-\mathrm{C}$ refractory was studied with respect to different firing temperatures and holding times. Most studies used a lower temperature $\left(\leq 1400{ }^{\circ} \mathrm{C}\right)$ for investigation, in order to avoid the indirect reaction, or only studied the single carbon content of the MgO-C refractory [14-16]. In general, the service temperature of the $\mathrm{MgO}-\mathrm{C}$ refractory is typically higher than 
$1500{ }^{\circ} \mathrm{C}$, thus it is necessary to study the oxidation behavior of the $\mathrm{MgO}-\mathrm{C}$ refractory with various carbon contents at higher temperatures.

$$
\begin{gathered}
2 \mathrm{C}(\mathrm{s})+\mathrm{O}_{2}(\mathrm{~g})=2 \mathrm{CO}(\mathrm{g}) \\
\mathrm{C}(\mathrm{s})+\mathrm{MgO}(\mathrm{s})=\mathrm{CO}(\mathrm{g})+\mathrm{Mg}(\mathrm{g})
\end{gathered}
$$

The wettability characteristics between molten slag and refractories are an important indicator for the slag corrosion resistance of the refractory, which is characterized by the contact angle between the solid-liquid phases $[17,18]$. In general, the refractories have superior slag corrosion resistance when they have poor wettability with molten slag [19]. Heo et al. [20] suggested that the carbon in the $\mathrm{MgO}-\mathrm{C}$ refractory effectively hindered the penetration of slags by repelling the slag and slowing the diffusion of $\mathrm{Mg}^{2+}$. Shen et al. [21] investigated the wettability between the $\mathrm{MgO}-\mathrm{C}$ substrate and the ladle furnace (LF) refining slag, where they found that the $\mathrm{MgO}-\mathrm{C}$ substrate remained un-wetted by the molten slag when the temperature was below $1460^{\circ} \mathrm{C}$. In fact, the wettability between $\mathrm{MgO}-\mathrm{C}$ refractories and molten slag depends on many factors, such as the carbon content, temperature, slag composition, and porosity of the MgO-C refractories [22,23]. However, there have been few efforts to investigate the effects of these factors on the slag corrosion resistance of the $\mathrm{MgO}-\mathrm{C}$ refractory through altering its wettability with slag $[24,25]$.

The oxidation resistance and the wettability characteristics were two vital factors regarding the service life of the $\mathrm{MgO}-\mathrm{C}$ refractory. However, few studies have combined the two aspects to investigate the effects that the carbon content has on the performance of the $\mathrm{MgO}-\mathrm{C}$ refractory. In this paper, the oxidation experiments of the $\mathrm{MgO}-\mathrm{C}$ refractories with various carbon contents were studied under different firing temperatures. The bulk density, apparent porosity, cold crushing strength (CCS), and oxidation rate of the fired $\mathrm{MgO}-\mathrm{C}$ refractories were measured and compared. Also, the contact angle between the molten slag and the $\mathrm{MgO}-\mathrm{C}$ refractories with various carbon contents were observed in-situ under an Ar atmosphere, and the wetting and penetration process of the molten slag within the $\mathrm{MgO}-\mathrm{C}$ refractories were analyzed.

\section{Experimental}

\section{1. $\mathrm{MgO}-\mathrm{C}$ Refractory Preparation}

The materials used for the preparation of the MgO-C refractory were magnesia with sizes of 1-3 mm, $0-1 \mathrm{~mm}$, and $<0.088 \mathrm{~mm}$, as well as flake graphite. The liquid resin and the aluminum metal powder were used as binders and anti-oxidant. Various compositions were formulated by varying the graphite content; see Table 1 for details. The raw materials were mixed for homogeneity, then pressed into a $50 \mathrm{~mm}$ cylindrical mold under a pressure of $200 \mathrm{MPa}$. The cylindrical $\mathrm{MgO}-\mathrm{C}$ refractories were cured at $200{ }^{\circ} \mathrm{C}$ for $24 \mathrm{~h}$.

Table 1. Composition of the $\mathrm{MgO}-\mathrm{C}$ refractories (mass\%).

\begin{tabular}{ccccc}
\hline Material & $\mathbf{1}$ & $\mathbf{2}$ & $\mathbf{3}$ & $\mathbf{4}$ \\
\hline MgO & 97 & 92 & 88 & 84 \\
Carbon & 3 & 8 & 12 & 16 \\
Al metal powder & +2 & +2 & +2 & +2 \\
Liquid resin & +4 & +4 & +4 & +4 \\
\hline
\end{tabular}

\subsection{Testing and Characterization Methods}

The oxidation resistance experiment was performed by firing the cured $\mathrm{MgO}-\mathrm{C}$ refractories in an electric resistance furnace (manufacturer, city, state, country). The MgO-C refractories were heated in the furnace to the specified temperature $\left(1400^{\circ} \mathrm{C}\right.$ or $\left.1600^{\circ} \mathrm{C}\right)$ for $3 \mathrm{~h}$ under an oxidizing atmosphere. The bulk 
density and the apparent porosity of the $\mathrm{MgO}-\mathrm{C}$ refractories were measured by via the Archimedes principle and calculated with Equations (3) and (4).

$$
\begin{gathered}
D=\frac{m_{0} D_{l}}{m_{2}-m_{1}} \\
q=\frac{m_{2}-m_{0}}{m_{2}-m_{1}}
\end{gathered}
$$

where $D$ and $q$ are the bulk density $\left(\mathrm{g} \cdot \mathrm{cm}^{-3}\right)$ and the apparent porosity $(\%)$ of the MgO-C refractories, respectively. $m_{0}$ is the mass of refractories in the air $(\mathrm{g}), m_{1}$ is the mass of the refractories in the water $(\mathrm{g}), m_{2}$ is the mass of the refractories with free bubbles on the surface $(\mathrm{g})$, and $D_{1}$ is the density of the water $\left(1.0 \mathrm{~g} \cdot \mathrm{cm}^{-3}\right)$.

The CCS of the MgO-C refractories was measured by using a compression testing machine (Constant Hydraulic Machinery Co. LTD., Zaozhuang, China) with a constant load rate, and the results were calculated with Equation (5). The mass, un-oxidized diameter, and height of the MgO-C refractory of both the initial state and after the oxidation were measured, and the mass loss rate and the oxidation rate of the refractories were calculated with Equations (6) and (7).

$$
\begin{gathered}
C=\frac{F}{A}=\frac{4 F}{\pi R_{0}^{2}} \\
r_{m}=\frac{m_{0}-m}{m_{0}} \times 100 \% \\
r_{o}=\frac{V_{0}-V}{V_{0}} \times 100 \%=\frac{R_{0}^{2} h_{0}-R^{2} h}{R_{0}^{2} h_{0}} \times 100 \%
\end{gathered}
$$

where the $C$ is the cold crushing strength, $F$ is the force imposed on the samples, $A$ is the sample's area, and $r_{\mathrm{m}}$ and $r_{\mathrm{O}}$ are the mass loss rate (\%) and the oxidation rate (\%), respectively. $m_{0}, V_{0}, R_{0}$, and $h_{0}$ are the mass $(\mathrm{g})$, volume $\left(\mathrm{mm}^{3}\right)$, diameter $(\mathrm{mm})$, and height $(\mathrm{mm})$, respectively, of $\mathrm{MgO}-\mathrm{C}$ refractories before oxidation. $m$ is the mass (g) of MgO-C refractories after oxidation; $V, R$, and $h$ are the volume $\left(\mathrm{mm}^{3}\right)$, diameter $(\mathrm{mm})$, and height $(\mathrm{mm})$ of the unoxidized area following oxidation.

The wetting behaviors of the $\mathrm{MgO}-\mathrm{C}$ refractories with molten slag were examined on the device shown in Figure 1. A $13 \mathrm{~mm} \times 2 \mathrm{~mm} \mathrm{MgO}-\mathrm{C}$ disc was prepared from the above MgO-C refractory. The prepared slag was mixed and pre-melted in an inducing furnace (Shenqiu Yongda High-frequency Equipment Co. LTD., Zhoukou, China) and the chemical composition, as shown in Table 2. The temperature of the furnace was raised and maintained at $1300{ }^{\circ} \mathrm{C}$. After the temperature was stabilized, the $\mathrm{MgO}-\mathrm{C}$ refractory disc with small granule slag was send to the furnace via the moving arm. The inert atmosphere was maintained throughout the experimental process to protect the $\mathrm{MgO}-\mathrm{C}$ refractory from oxidation. A high-speed camera captured and restored images of the MgO-C refractory wetting process. The shape parameters of the molten slag, such as the apparent radius and height, were measured by analyzing the images.

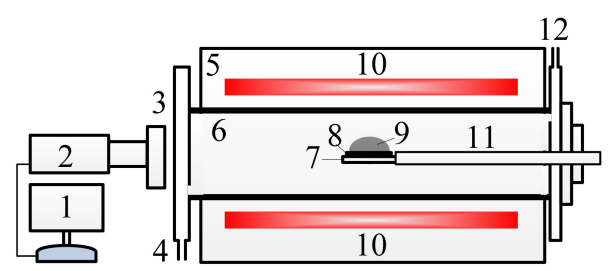

Figure 1. Schematic experimental setup of the wetting process. 1 Recorder, 2 High speed camera, 3 Quartz window, 4 Gas inlet, 5 Furnace, 6 Alumina tube, 7 Stage, 8 MgO-C refractory, 9 Slag, 10 Heating element, 11 Moving arm, 12 Gas outlet. 
Table 2. Chemical composition of the experimental slag (mass \%).

\begin{tabular}{ccccccc}
\hline $\mathrm{CaO}$ & $\mathrm{SiO}_{2}$ & $\mathrm{Al}_{2} \mathrm{O}_{3}$ & $\mathrm{~V}_{\mathbf{2}} \mathrm{O}_{5}$ & $\mathrm{Fe}_{2} \mathrm{O}_{3}$ & $\mathrm{MnO}$ & $\mathrm{TiO}_{2}$ \\
\hline 45.87 & 35.52 & 13.65 & 1.90 & 1.68 & 0.72 & 0.66 \\
\hline
\end{tabular}

\section{Results and Discussion}

\subsection{Oxidation Resistance}

The oxidation resistance of the $\mathrm{MgO}-\mathrm{C}$ refractories with various carbon contents were measured and compared by firing the refractories at $1400{ }^{\circ} \mathrm{C}$ and $1600{ }^{\circ} \mathrm{C}$. The bulk density, apparent porosity, $\mathrm{CCS}$, oxidation rate, and mass loss rate of the fired $\mathrm{MgO}-\mathrm{C}$ refractories were examined.

Figure 2a depicts the bulk density of the cured and fired $\mathrm{MgO}-\mathrm{C}$ refractories with various carbon contents. The lower density of carbon caused the bulk density of the $\mathrm{MgO}-\mathrm{C}$ refractories to decrease as the carbon content increased. The bulk density of the refractories markedly decreased after firing, which was more evident with the higher carbon content. The apparent porosity of the fired $\mathrm{MgO}-\mathrm{C}$ refractories increased as the carbon content increased (Figure 2b), which caused by the greater carbon oxidation present and more additional porous structures create in the higher carbon content. It is worthwhile to mention that the $1600{ }^{\circ} \mathrm{C}$ batch obtained higher bulk density and lower apparent porosity of the fired refractories.

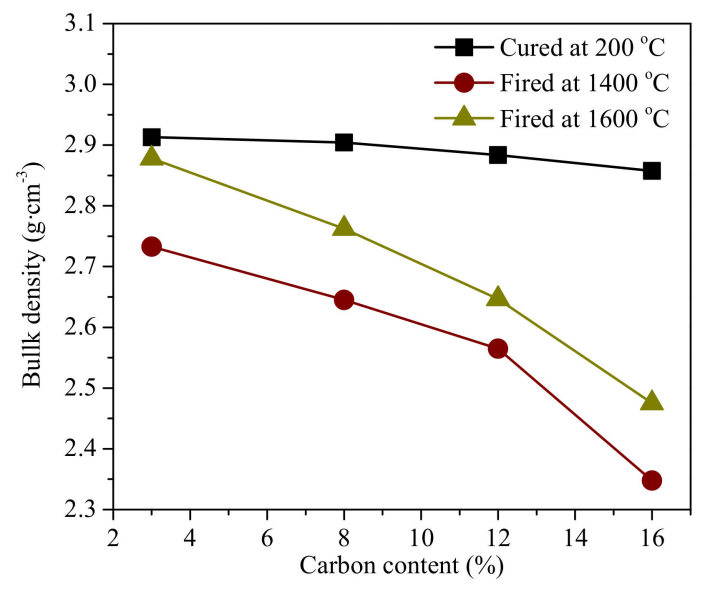

(a)

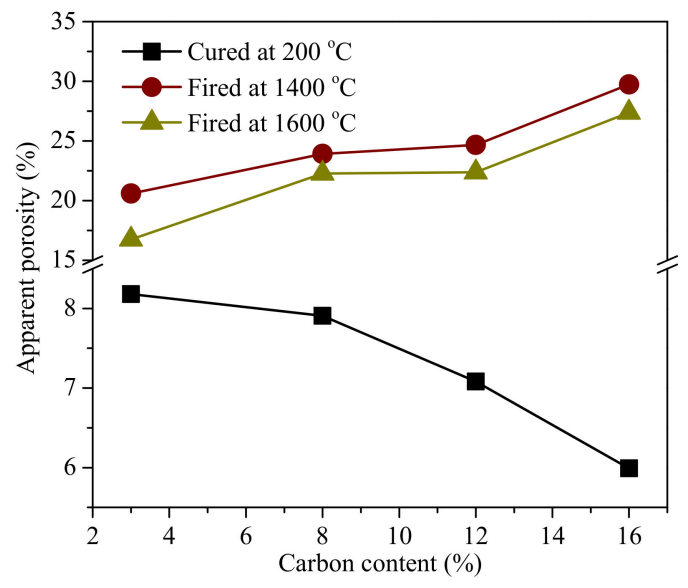

(b)

Figure 2. Bulk density (a) and apparent porosity (b) of the cured and fired $\mathrm{MgO}-\mathrm{C}$ refractories.

Figure 3 shows the CCS values of the cured and fired $\mathrm{MgO}-\mathrm{C}$ refractories. With the same tendency of the bulk density are shown in Figure 2a, where the CCS value decreased as the carbon content increased in the three batches, and the $1600{ }^{\circ} \mathrm{C}$ batch had a more moderate value than the other two batches. The CCS failure of the fired MgO-C refractories, especially in higher carbon content, was due to the abundant pores that were generated by the carbon oxidation, which made the composition weak and fragile. The changed trends of CCS were in agreement with those reported [12] by other researchers. 


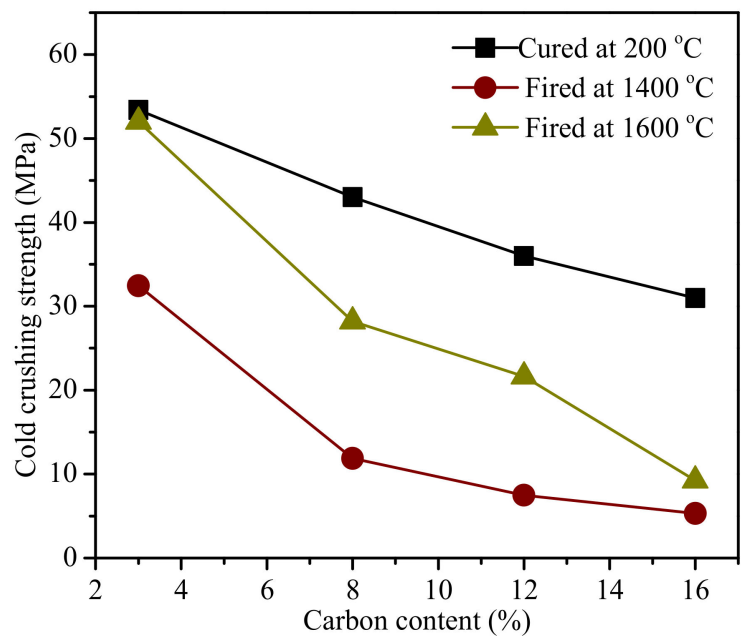

Figure 3. Cold crushing strength of the cured and fired $\mathrm{MgO}-\mathrm{C}$ refractories.

Figure 4 shows the longitudinal section of the fired $\mathrm{MgO}-\mathrm{C}$ refractories under two different firing temperatures. The boundary between the non-oxidized core and the completely oxidized exterior shell was present, and the oxidized exterior shell decreased as the carbon content increased both of the two batches. The volumes of the original and the non-oxidized core after oxidation were calculated and the oxidation rates are shown in Figure $5 \mathrm{a}$. When the carbon content of $\mathrm{MgO}-\mathrm{C}$ refractories were $3 \%$ and $8 \%$, the oxidation rate of the $1600{ }^{\circ} \mathrm{C}$ batch was obviously smaller than the $1400{ }^{\circ} \mathrm{C}$ batch, while the two batch values were became almost the same when the carbon content were raised to $12 \%$ and $16 \%$. The mass loss rate of the fired $\mathrm{MgO}-\mathrm{C}$ refractories is show in Figure $5 \mathrm{~b}$. There were differences within the trends of oxidation rates, which increased as the carbon content increased.
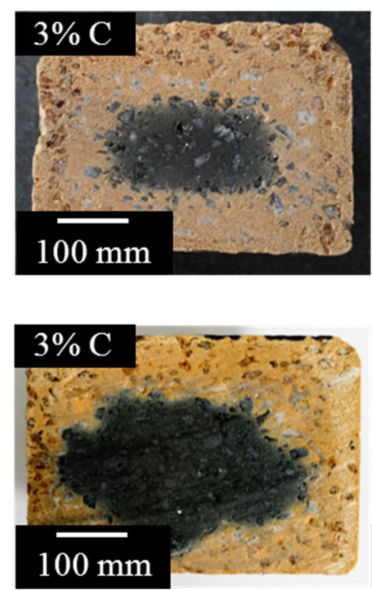

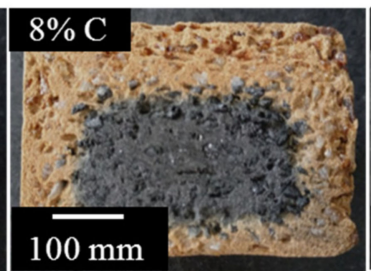

$100 \mathrm{~mm}$

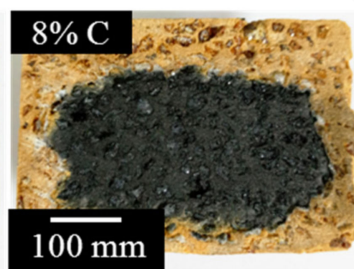

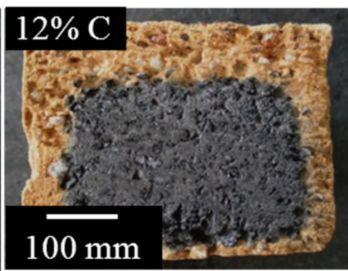

(a)

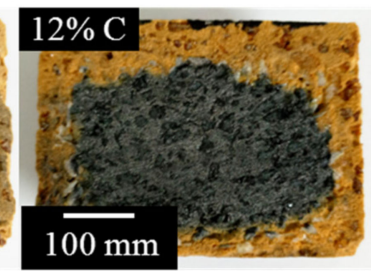

(b)
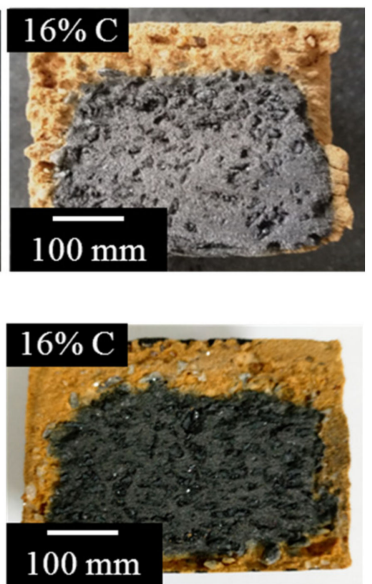

Figure 4. Longitudinal sections of the fired $\mathrm{MgO}-\mathrm{C}$ refractories at: (a) $1400{ }^{\circ} \mathrm{C}$ and (b) $1600{ }^{\circ} \mathrm{C}$. 


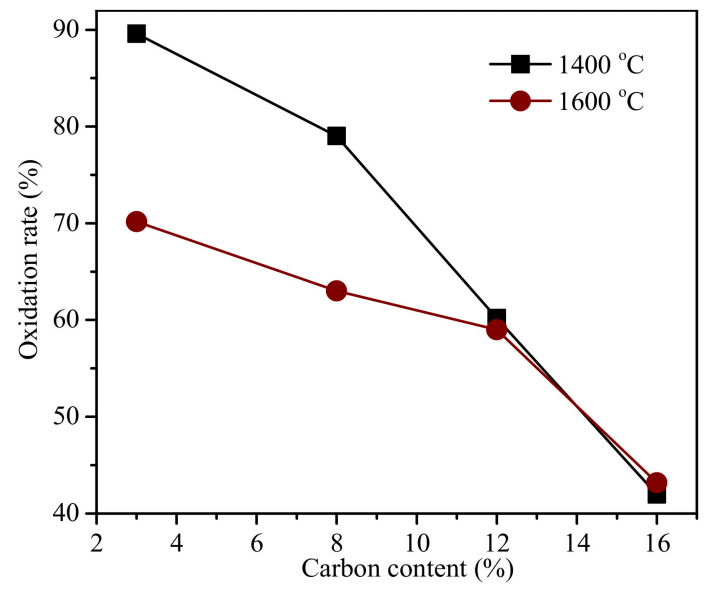

(a)

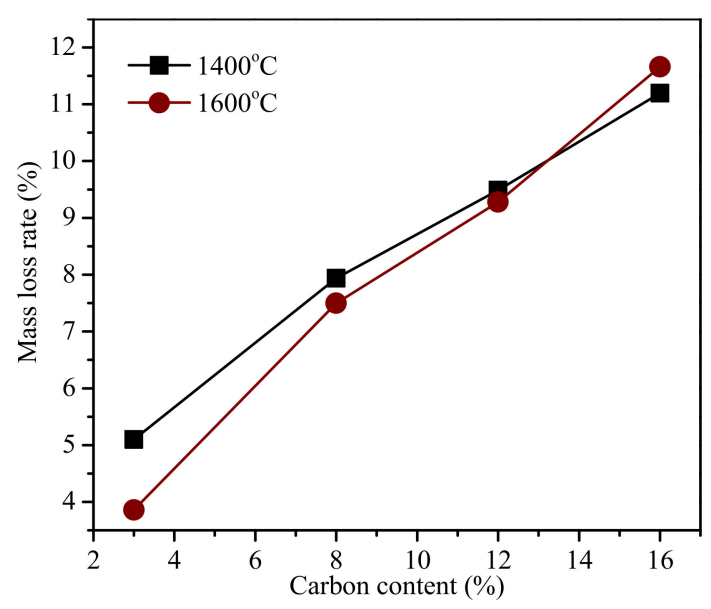

(b)

Figure 5. Oxidation rate (a) and mass loss rate (b) of the fired $\mathrm{MgO}-\mathrm{C}$ refractories.

The carbon oxidation of $\mathrm{MgO}-\mathrm{C}$ refractory fired at $1400{ }^{\circ} \mathrm{C}$ was direct oxidation (Equation (1)). However, the situation became more complicated when fired at $1600^{\circ} \mathrm{C}$. The carbon oxidation of the $\mathrm{MgO}-\mathrm{C}$ refractory was the comprehensive result of the direct (Equation (1)) and the indirect (Equation (2)) oxidation. The indirect oxidation reaction of the carbon generated $\mathrm{Mg}$ vapor, which diffused outside, through the porous structure of $\mathrm{MgO}-\mathrm{C}$ refractory, where it came in contact with oxygen and reoxidized to $\mathrm{MgO}$ (Equation (8)). The regenerated $\mathrm{MgO}$ filled up the pores and impeded additional oxygen from entering, furthering the oxidation to some extent. Therefore, the oxidation was restrained in the $1600{ }^{\circ} \mathrm{C}$ batch, which was seen in the longitudinal section morphology of the fired $\mathrm{MgO}-\mathrm{C}$ refractory (Figure 4). The indirect oxidation effects were also reflected in the other parameters, such as the higher density and CCS value, and lower porosity and mass loss rate of the fired refractory at $1600{ }^{\circ} \mathrm{C}$. As the carbon content increased, more porous structures were generated after the carbon oxidation. The pores filled with the deposited $\mathrm{MgO}$ were limited under the high carbon content of $\mathrm{MgO}-\mathrm{C}$ refractory, which caused the temperature effect to be more pronounced when the carbon content was lower. Similar results were found for MgO-C composite containing $5 \mathrm{wt} \%$ [26] and $20 \mathrm{wt} \%$ [27] carbon in previous study. In their investigation, the oxidation rates were decreased when the temperature exceeded $1400{ }^{\circ} \mathrm{C}$. They explained that the formation of a continuous dense layer on the outer brick surface restricted the oxidation of low carbon containing $\mathrm{MgO}-\mathrm{C}$ refractory.

$$
2 \mathrm{Mg}(\mathrm{g})+\mathrm{O}_{2}(\mathrm{~g})=2 \mathrm{MgO}(\mathrm{s})
$$

\subsection{Wetting Behavior}

Figure $6 \mathrm{~b}-\mathrm{e}$ show the wetting process of the various carbon contents of the $\mathrm{MgO}-\mathrm{C}$ refractories with molten slag at $1300{ }^{\circ} \mathrm{C}$. The wetting behavior of molten slag in the pure $\mathrm{MgO}$ (Figure 6a) and the graphite (Figure 6f) disc were studied for comparisons with the $\mathrm{MgO}-\mathrm{C}$ refractories. The contact angle between the samples and the molten slag was measured; the results are shown in Figure 7. 


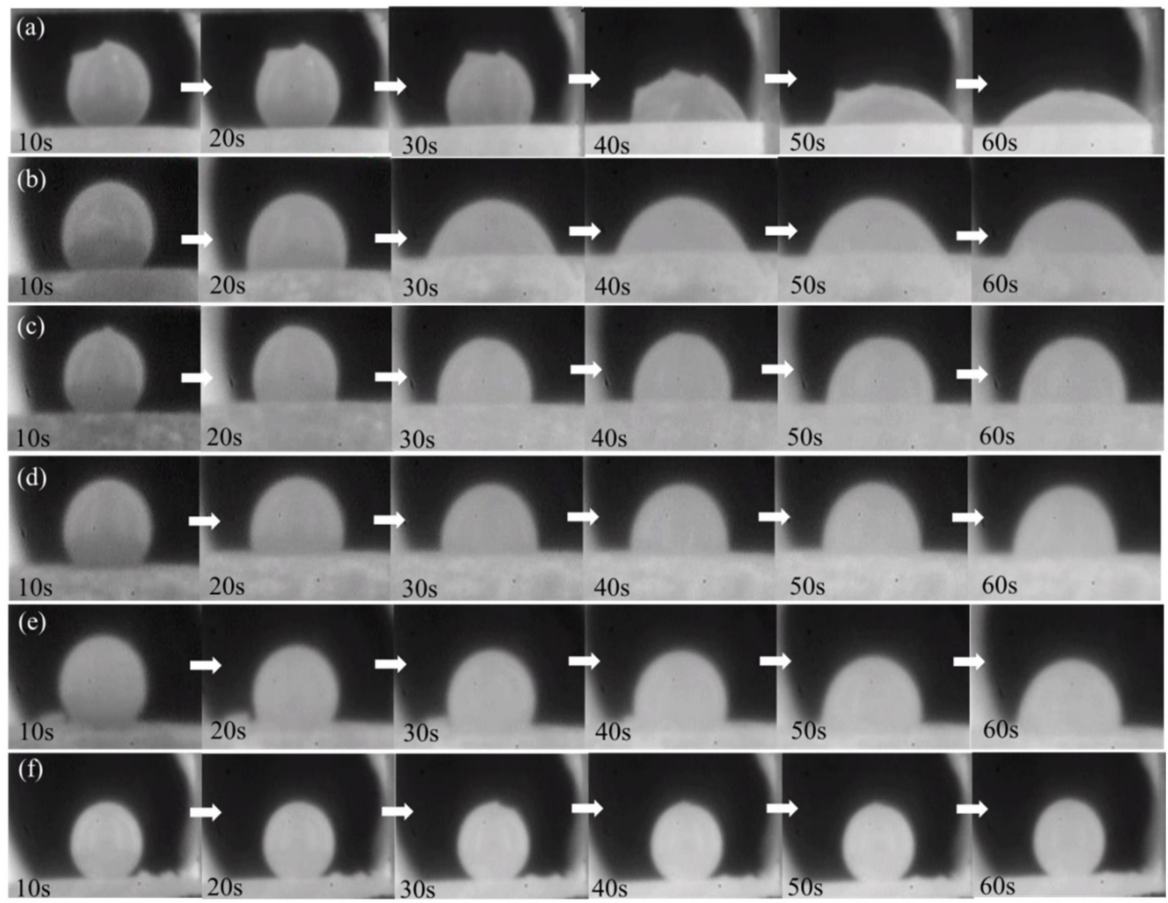

Figure 6. Wetting process of $\mathrm{MgO}-\mathrm{C}$ refractories with the molten slag: (a) pure $\mathrm{MgO},(\mathbf{b}) 3 \% \mathrm{C}$, (c) $8 \%$ C, (d) $12 \%$ C, (e) $16 \%$ C, and (f) pure graphite.

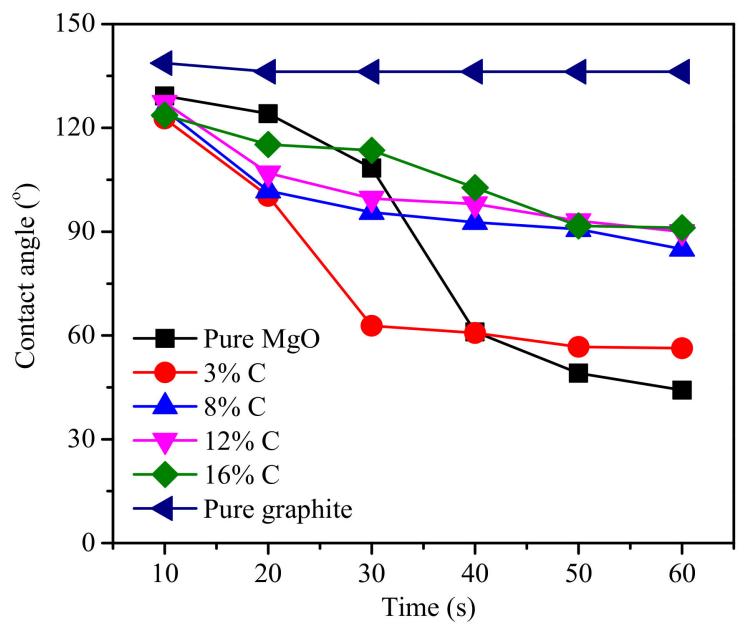

Figure 7. Contact angle between the samples and the molten slag.

The molten slag spread to the surface of sample materials and the contact angles between them decreased as the wetting process progressed (Figures 6 and 7). The contact angle between the molten slag and the pure carbon was about $140^{\circ}$ and changed little with time, while the situation was totally different when it came to the pure $\mathrm{MgO}$ and $\mathrm{MgO}-\mathrm{C}$ refractories. The contact angle between molten slag and pure $\mathrm{MgO}$ fiercely decreased from $129.2^{\circ}$ to $61.0^{\circ}$ within $30 \mathrm{~s}$, and decreased from $122.7^{\circ}$ to $62.8^{\circ}$ within $20 \mathrm{~s}$ for the refractory with the $3 \%$ carbon content. The decrease of the contact angle was not as abrupt when the carbon content were $8 \%, 12 \%$, and $16 \%$, where there was little difference in the three different carbon content within the $60 \mathrm{~s}$. Yuan et al. [22] studied the wettability between molten slag and $\mathrm{MgO}-\mathrm{C}$ refractories. In their study, the contact angle reached the steady state needs longer time $(237 \mathrm{~s})$. It is mainly due to the high basicity $(\mathrm{C} / \mathrm{S}=3.3)$ and high carbon containing $\mathrm{MgO}-\mathrm{C}$ refractories $(\mathrm{C} \% \geq 18 \%)$ they used. 
The error that was caused by the slightly quality differences of the molten slag within the different samples was eliminated by using the ratio to the shape parameters (apparent radius and height) of molten slag at $10 \mathrm{~s}$ (Figure 8). The apparent volume of the molten slag was calculated according to the crown model (Figure 9a and Equation (9)), and the ratio of volume (ratio to the value at $10 \mathrm{~s}$ ) is shown in Figure 9b. The change of apparent volume was strongly associated with the carbon content. For example, the apparent volume was changed slightly when the molten slag came in contact with pure carbon, while it was markedly decreased when the molten slag came in contact with the pure $\mathrm{MgO}$ and the refractory with 3\% carbon content. When the carbon content in the composition was between $8 \%$ and $16 \%$, the apparent volume change over time was basically the same and the values were between the pure carbon and the $3 \%$ carbon content.

$$
\begin{gathered}
V=\frac{1}{3} \pi\left[2 R^{3}(1-\cos \theta)-r^{2}(R-h)\right] \\
R=\frac{r^{2}+h^{2}}{2 h} \\
\theta=\sin ^{-1} \frac{2 r h}{r^{2}+h^{2}}
\end{gathered}
$$

where $V$ is the apparent volume of molten slag, $r$ is the apparent radius, and $h$ is the apparent height; $\theta$ is the contact angle of between the molten slag and the $\mathrm{MgO}-\mathrm{C}$ refractory; and $R$ is the crown diameter. $R$ and $\theta$ are the functions of $r$ and $h$, which were calculated from Equations (10) and (11) [17].

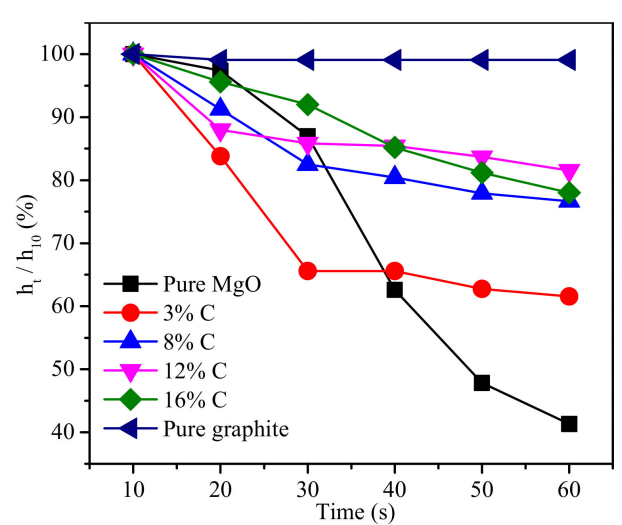

(a)

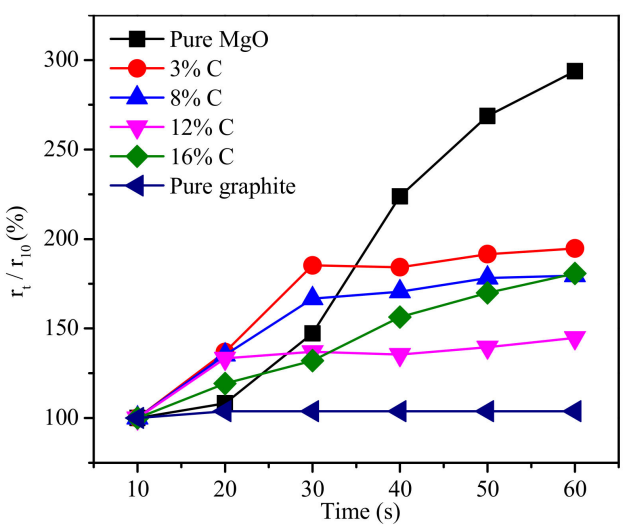

(b)

Figure 8. Changes of the apparent height (a) and the apparent radius (b) of the molten slag.

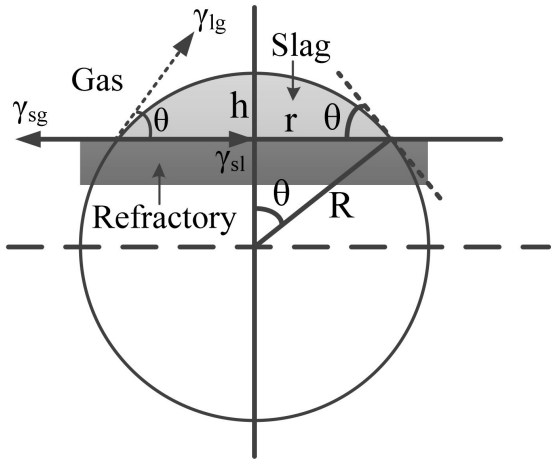

(a)

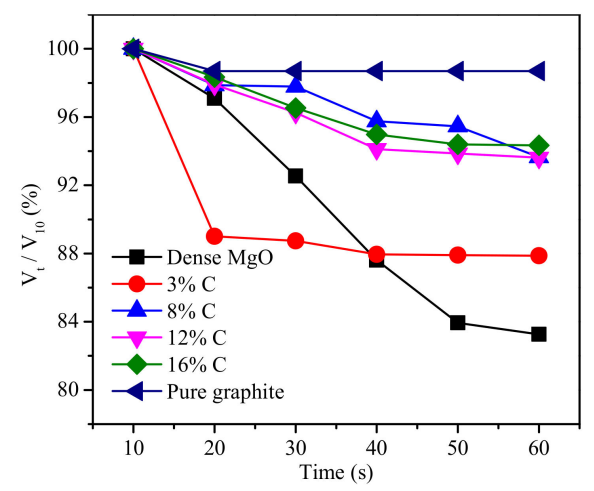

(b)

Figure 9. Crown model (a) and calculated apparent volume (b) of the molten slag. 
The decreased apparent volume over time suggested that the molten slag spread while it penetrated into the refractories. The extent of penetration within the molten slag into refractory was expressed by the absorption force, which was determined by the surface tension between liquid and vapor, the contact angle, and the capillary radius (Equation (12)) [24,28]. There was only a very short time at the start of the melting that was detected, it was assumed that the composition of the slag was unchanged. Therefore, the surface tension between liquid and vapor was basically unchanged. At the same time, the porosity of different refractories mostly ranged between $6 \%$ and $8 \%$ (Figure $2 b$ ). So, the absorption force had the highest correlation with the contact angle. In fact, Figures 7 and $9 \mathrm{~b}$ illustrate the close relationship between the change of contact angle and apparent volume. The smaller contact angle corresponded the reduced apparent volume, which indicated a deeper penetration of the molten slag into the refractory (Figure 10). Shen et al. [21] studied the LF refining slag and MgO-C substrate, and also claimed that the molten slag penetrated into the substrate once the contact angle was smaller than $90^{\circ}$.

$$
\Delta P=\left(2 \gamma_{\mathrm{lv}} \cdot \cos \theta\right) / r
$$

where $\Delta P$ is the absorption force of the capillary phenomena, $\gamma_{1 v}$ is the surface tension of the liquid-vapor, $\theta$ is the contact angle, and $r$ is the radius of capillary.

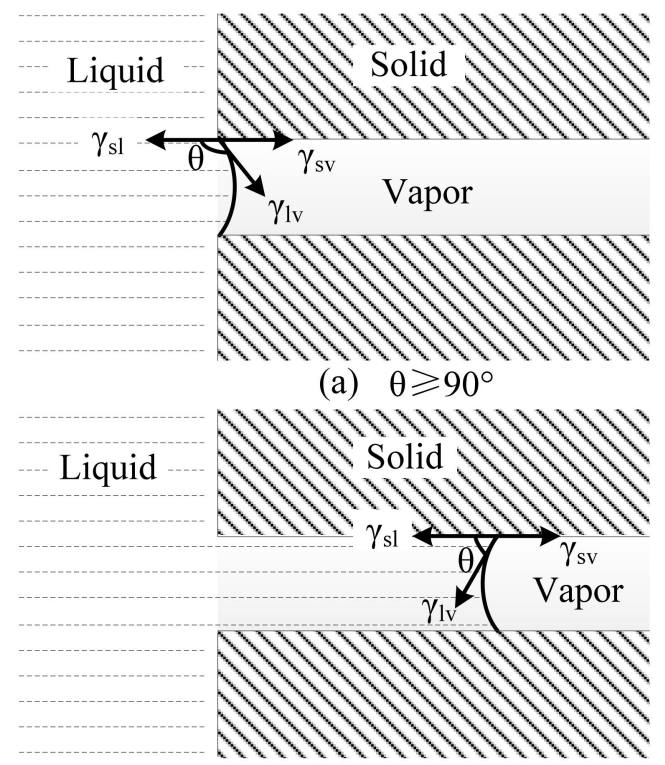

(b) $\theta<90^{\circ}$

Figure 10. Schematic diagram of the relationship between the contact angle and the penetration (a) $\theta \geq 90^{\circ}$; and (b) $\theta<90^{\circ}$.

\section{Conclusions}

The oxidation resistance of the MgO-C refractory was studied by comparing the bulk density, apparent porosity, cold crushing strength, and oxidation rate of the fired refractories with different carbon contents. The wetting behavior of the $\mathrm{MgO}-\mathrm{C}$ refractory with molten slag was observed in-situ, and the contact angle and apparent volume were compared. The results were as follows:

1. The bulk density, apparent porosity, and cold crushing strength of the cured MgO-C refractory decreased as the carbon content increased. These properties degraded after firing, especially at higher carbon content.

2. The regenerated $\mathrm{MgO}$ in the $\mathrm{MgO}-\mathrm{C}$ refractory effectively hindered the carbon oxidation in the lower carbon content, and increased the cold crushing strength and bulk density of the fired refractory to some extent. 
3. The molten slag penetration into the $\mathrm{MgO}-\mathrm{C}$ refractory, which decreased the apparent volume during the wetting process. The penetration extent was closely related to the contact angle between the $\mathrm{MgO}-\mathrm{C}$ refractory and the molten slag.

Author Contributions: Jingkun Yu and Zhaoyang Liu conceived and designed the experiments. Zhaoyang Liu, Xin Yang, and Endong Jin performed the experiments. Zhaoyang Liu performed data analysis and wrote this paper. Jingkun Yu and Lei Yuan revised the paper.

Funding: This research received no external funding.

Acknowledgments: The authors wish to express their appreciation for the Institute of High Temperature Materials and Technology for Metallurgy, Northeastern University.

Conflicts of Interest: The authors declare no conflict of interest.

\section{References}

1. Zhang, S.W.; Lee, W.E. Influence of additives on corrosion resistance and corroded microstructures of MgO-C refractories. J. Eur. Ceram. Soc. 2001, 21, 2393-2405. [CrossRef]

2. Li, Z.; Mukai, K.; Tao, Z. Reactions between MgO-C refractory, molten slag and metal. ISIJ Int. 2000, 40, 101-105. [CrossRef]

3. Zhu, T.; Li, Y.; Sang, S.; Xie, Z. Mechanical behavior and thermal shock resistance of MgO-C refractories: Influence of graphite content. Ceram. Int. 2017, 43, 7177-7183. [CrossRef]

4. Liu, Q.C.; Chen, D.F.; Xu, Y.; Newkirk, J.W. Corrosion resistance of MgO-C refractory to smelting reduction slag containing titania. Brit. Corros. J. 2002, 37, 231-234. [CrossRef]

5. Han, B.; Ke, C.; Wei, Y.; Yan, W.; Wang, C.; Chen, F.; Li, N. Degradation of MgO-C refractories corroded by $\mathrm{SiO}_{2}-\mathrm{Fe}_{2} \mathrm{O}_{3}-\mathrm{V}_{2} \mathrm{O}_{5}-\mathrm{TiO}_{2}-\mathrm{MnO}-\mathrm{MgO}$ slag. Ceram. Int. 2015, 41, 10966-10973. [CrossRef]

6. Mukai, K.; Li, Z.; Tao, Z. Bubble generation in MgO-C crucible charged with slag and metal in relation to local corrosion. High Temp. Mater. Process. 2011, 20, 255-262. [CrossRef]

7. Jansson, S.; Brabie, V.; Jonsson, P. Corrosion mechanism of commercial MgO-C refractories in contact with different gas atmospheres. ISIJ Int. 2008, 48, 760-767. [CrossRef]

8. Jansson, S.; Brabie, V.; Bohlin, L. Corrosion mechanism and kinetic behaviour of refractory materials in contact with $\mathrm{CaO}-\mathrm{Al}_{2} \mathrm{O}_{3}-\mathrm{MgO}-\mathrm{SiO}_{2}$ slags. Scand. J. Metall. 2004, 34, 283-292. [CrossRef]

9. Zhu, T.; Li, Y.; Sang, S.; Xie, Z. Fracture behavior of low carbon MgO-C refractories using the wedge splitting test. J. Eur. Ceram. Soc. 2017, 37, 1789-1797. [CrossRef]

10. Sadrnezhaad, S.K.; Mahshid, S.; Hashemi, B.; Nemati, Z.A. Oxidation mechanism of C in MgO-C refractory bricks. J. Am. Ceram. Soc. 2006, 89, 1308-1316. [CrossRef]

11. Li, X.; Rigaud, M. Anisotropy of the properties of magnesia-graphite refractories: linear thermal change and carbon oxidation resistance. Can. Ceram. Q. 1993, 62, 197-205.

12. Pilli, V.; Sarkar, R. Nanocarbon containing $\mathrm{Al}_{2} \mathrm{O}_{3}-\mathrm{C}$ continuous casting refractories: effect of graphite content. J. Alloys Compd. 2018, 735, 1730-1736. [CrossRef]

13. Li, X.; Rigaud, M.; Palco, S. Oxidation kinetics of graphite phase in magnesia-carbon refractories. J. Am. Ceram. Soc. 1995, 78, 965-971. [CrossRef]

14. Faghihi-Sani, M.A.; Yamaguchi, A. Oxidation kinetics of MgO-C refractory bricks. Ceram. Int. 2002, 28, 835-839. [CrossRef]

15. Sadrnezhaad, S.K.; Nemati, Z.A.; Mahshid, S.; Hosseini, S.; Hashemi, B. Effect of Al antioxidant on the rate of oxidation of carbon in MgO-C refractory. J. Am. Ceram. Soc. 2007, 90, 509-515. [CrossRef]

16. Hashemi, B.; Nemati, Z.A.; Faghihi, M.A. Effects of resin and graphite content on density and oxidation behavior of MgO-C refractory bricks. Ceram. Int. 2006, 32, 313-319. [CrossRef]

17. Yoon, T.; Lee, K.; Lee, B.; Chung, Y. Wetting, spreading and penetration phenomena of slags on $\mathrm{MgAl}_{2} \mathrm{O}_{4}$ spinel refractories. ISIJ Int. 2017, 57, 1327-1333. [CrossRef]

18. Kim, S.; Lee, K.; Chung, Y. Dissolutive wetting and spreading phenomena between $\mathrm{Al}_{2} \mathrm{O}_{3}$ substrate and $\mathrm{CaO}-\mathrm{Al}_{2} \mathrm{O}_{3}$ liquid slags. Metall. Mater. Trans. B 2016, 47, 1209-1216. [CrossRef]

19. Hemberger, Y.; Berthold, C.; Nickel, K.G. Wetting and corrosion of yttria stabilized zirconia by molten slags. J. Eur. Ceram. Soc. 2012, 32, 2859-2866. [CrossRef] 
20. Heo, S.H.; Lee, K.; Chung, Y. Reactive wetting phenomena of MgO-C refractories in contact with $\mathrm{CaO}-\mathrm{SiO} 2$ slag. Trans. Nonferrous Met. Soc. China 2012, 22, 870-875. [CrossRef]

21. Shen, P.; Zhang, L.F.; Wen, Y.; Wang, Y. Wettability and penetration phenomenon between LF refining slag and MgO-C substrate. Iron Steel 2016, 51, 31-40. (in Chinese).

22. Yuan, Z.; Wu, Y.; Zhao, H.; Matsuura, H.; Tsukihashi, F. Wettability between molten slag and MgO-C refractories for the slag splashing process. ISIJ Int. 2013, 53, 598-602. [CrossRef]

23. Mukai, K. Wetting and marangoni effect in iron and steelmaking processes. ISIJ Int. 1992, 32, 19-25. [CrossRef]

24. Mills, K.C.; Hondros, E.D.; Li, Z. Interfacial phenomena in high temperature processes. J. Mater. Sci. 2005, 40, 2403-2409. [CrossRef]

25. Li, X.; Zhu, B.; Wang, T. Effect of electromagnetic field on slag corrosion resistance of low carbon MgO-C refractories. Ceram. Int. 2012, 38, 2105-2109. [CrossRef]

26. Leonard, R.J.; Herron, R.H. Significance of oxidation-reduction reactions within BOF refractories. J. Am. Ceram. Soc. 1972, 55, 1-6. [CrossRef]

27. Ghosh, N.K.; Ghosh, D.N.; Jagannathan, K.P. Oxidation mechanism of MgO-C in air at various temperatures. Brit. Ceram. Trans. 2000, 99, 124-128. [CrossRef]

28. Tsypkin, G.G.; Calore, C. Role of capillary forces in vapour extraction from low-permeability, water-saturated geothermal reservoirs. Geothermics 2003, 32, 219-237. [CrossRef]

(C) 2018 by the authors. Licensee MDPI, Basel, Switzerland. This article is an open access article distributed under the terms and conditions of the Creative Commons Attribution (CC BY) license (http://creativecommons.org/licenses/by/4.0/). 